This is a peer-reviewed, accepted author manuscript of the following research article: Manjon, M-J., Merino, A., \& Cairns, I. (2021). Tackling energy poverty through social intrapreneurship in large-scale energy companies. Social Enterprise Journal. https://doi.org/10.1108/SEJ-11-2020-0103

\title{
TACKLING ENERGY POVERTY THROUGH SOCIAL INTRAPRENEURSHIP IN LARGE-SCALE ENERGY COMPANIES
}

\begin{abstract}
Purpose

The purpose of this paper is to present advances towards a social intrapreneurship department within energy corporations. By drawing on the literature on social intrapreneurship and stakeholder theory, we provide a conceptual proposal for an organizational structure. We build on the notion of bridging and boundary organizations, to suggest an organizational innovative structure as a social intrapreneurship endeavour focusing on the increasing salience of weak stakeholders in energy corporations from energy justice approach.
\end{abstract}

\section{Design/methodology/approach}

Conceptual paper

\section{Findings}

The results are presented in a conceptual process model for the development of Social Energy Department units within large energy companies, illustrating their embeddedness in both societal and company-level processes to facilitate social intrapreneurship initiatives that would alleviate energy poverty in the just transition.

\section{Practical implications}


The paper promises novel insights at the nexus of social enterprise and organizational change. The practical applicability is particularly promising since it focuses on integrating novel units in energy companies and stimulates further research on models of social intrapreneurship to tackle energy poverty.

\section{Originality/value}

The paper offers both practical and theoretical contributions to the stakeholder theory field with insights from social intrapreneruship and organisational stakeholder theory in the context of a specific social problem - energy poverty, energy justice and the just energy transition.

Keywords: social intrapreneurship, social entrepreneurship, organisational change, stakeholder theory, energy poverty, bridging departments, boundary spanning, just energy transition

\section{Conceptual article}




\section{Introduction}

The pathways towards the low-carbon energy transition face the challenge of being inclusive towards energy-vulnerable households, which is an issue of growing interest, particularly in Europe (Hiteva, 2013). Energy poverty refers to the difficulty or inability of a household to maintain adequate temperature conditions, as well as other essential energy domestic services, at a reasonable price, and it is estimated to affect more than 50 million people in Europe (Thomson and Bouzarovski, 2018). COVID-19 may have a strong influence on the expansion of energy poverty, and therefore, this number is likely to grow (Sumner et al., 2020). If not properly addressed through an attempted resolve coordinated by all actors, the consequences of COVID19 may affect a greater number of vulnerable people, thus increasing energy poverty. Although there is no universally accepted definition of energy poverty, it is widely recognised that energy services, such as heating, cooling, or refrigerating food, are necessary for people's health and to enable effective participation in society (Bouzarovski and Simcock, 2017; Day et al., 2016).

Energy poverty has been predominantly attributed to the triad of insufficient income, high energy prices, and energy inefficiency, but other approaches view this delimitation as incomplete because it does not take into account those causes of a more human-centred nature (Boni et al., 2016). Moreover, given its systemic, multidimensional, and frequently invisible nature, energy poverty can be characterised as a complex problem that requires the coordinated participation of multiple interrelated actors through complex interventions (Van Tulder and Keen, 2018; Waddock et al., 2015). The current institutionalized designs in energy corporations deal peripherally with vulnerable energy customer communities but fail to tap into their high potential to alleviate energy poverty. Therefore, approaches that bridge disciplines and domains may be particularly appropriate to address energy poverty issues (Sovacool, 2014). 
In this conceptual work, we examine the emerging relevance of social entrepreneurship issues within the field of energy social science to provide partial solutions to tackle energy poverty (Martiskainen et al., 2018; Sovacool, 2014). We argue that social enterprises are a productive space that may provide a proper logic to build broader and more effective responses to the problem of energy vulnerability.

Social entrepreneurship is an innovation space dominated by relatively few entities with a large capacity for leveraging resources within the network (Dacin et al., 2011). Due to their limited power and resources, few social entrepreneurs have become large enough to strongly influence government and policy makers (Montgomery et al., 2012). Their agency in the economic ecosystem in the context of just energy transitions requires some clarification (Mair and Marti, 2006). As this is an innovation niche, there is a risk that it may disappear, although it could survive if such a niche reaches the necessary degree of maturity.

A greater change is needed for energy companies to move in the direction of energy justice (van Tulder, 2018; Waddock et al., 2015). Large companies are increasingly recognised as market/technology/value innovators, although little research focuses on their high potential as social innovators (Barnett, 2019). Perceived as resistant to change, energy companies could become proactive agents in energy transition since their power is highly influential (Turnheim and Sovacool, 2019) and they are watched closely by society, mainly because power supply is an essential service (Perez-Arriaga et al., 2017). The resources of large-scale companies could support experimentation with social intrapreneurship models despite the traditional position of these companies regarding radical changes, i.e., being against radical change (Jenkins et al., 2020; Wesseling et al., 2020). In transitions, it is acknowledged that disruptive change occurs as an outcome of the various multilevel relationships existing in a specific context, where conflict 
exists between the dominant entity (actors, structures, and practices) and the new emerging alternatives (Araújo, 2014; Geels, 2002; Geels and Schot, 2007). There has been very little research on these two levels of the agency of company actors in transitions (Hörisch, 2015), i.e., first, on the level of the emerging niche of social intrapreneurs as innovators in energy poverty (Hiteva and Sovacool, 2017) and second, on the level of the existing large-scale energy companies (energy companies). The unique position of these companies as influential actors could transform large energy companies to help alleviate poverty (Halme et al., 2010; Turnheim and Sovacool, 2019).

We intend to respond to this need by proposing a conceptual process model for structured organisational change to implement multiactor collaboration (Van Zanten and Van Tulder, 2018) through integrating social intrapreneurship departments (Nandan et al., 2014) within energy companies to minimise energy poverty. The current structures within corporations, such as corporate foundations or other non-single mission departments, have very limited effects on minimising energy poverty. To date, vulnerable energy consumers continue to be the weaker stakeholders of the corporation. Specifically, we illustrate the proposal with the introduction of a new department in the organisational structure of an energy company that would deal directly with vulnerable customers, the Social Energy Department (the SED). The specific details of the business model would be designed on a case-by-case basis and are not addressed in this paper. The introduction of a new logic does not mean substitution but rather involves interaction and adaptation between actors on a gradual path towards transformation (Schot and Geels, 2008).

In the context of energy transition, minimising energy poverty constitutes a part of Sustainable Development Goals (SDGs) 1 and 7 and such a nonbinding legal framework is adequate to tackle energy poverty (Van Zanten and Van Tulder, 2018). Global goals may 
advance with public and private efforts (Biermann et al., 2017), and companies may fill in the gaps that states are no filling by covering the so-called institutional voids (Mair and Marti, 2006; van Tulder, 2018).

To this end, we seek to answer the following two research questions: How and why would the logic of social intrapreneurship within large-scale energy companies be an effective response to the challenges of energy poverty in the framework of a just energy transition?

To achieve this objective, within the energy poverty and transition context, this paper examines a related interdisciplinary background in the social entrepreneurship and intrapreneurship, organisational change, and stakeholder theories. Therefore, our proposal illustrates a method that builds and includes a novel organisational unit though departments formed by social intrapreneurs in incumbent energy companies that are united to tackle energy poverty. Centred on this conceptual basis, the objective is the defence of a model for large-scale companies to adapt to just energy transitions with an organisational change led by a vision to impact the stakeholders map and to protect the basic energy rights linked to the core of the business.

\section{Background}

Within the context of the energy poverty and transition literature, this conceptual paper builds on the literature relevant to the agency of social intrapreneurship with the underlying organisational question in relation to stakeholders.

The perspective of the participation of large firms in a just energy transition (Hockerts and Wüstenhagen, 2010) may grant social intrapreneurs a more prominent role that will enable them to survive and accelerate the just transition through the disciplinary lens of organisational 
change theory, particularly in terms of their organisation bridging and boundary spanning roles (Aldrich and Herker, 1977; Berkes, 2009). Relatively new logic could be integrated into old systems that need to be reinvented. It is not a contradiction to encourage the integration of two currently distant actors.

Energy poverty is the context of the study and the social problem to be addressed. Understanding the complexities of energy poverty as a dimension of poverty needs to be carefully treated so that a naturally distant actor, such as a large-scale energy company, is willing to address it. Previous studies have looked at energy poverty with a partial focus (Boardman, 1991; Bouzarovski and Petrova, 2015). The existence of different perspectives addressing a complex problem demonstrates the need to adopt multilevel, multidimensional and multiactor approaches in the energy poverty field (Sovacool, 2014). The contributions of social entrepreneurship to fighting energy poverty are significantly increasing and demonstrate how social entrepreneurs act as bridge builders between vulnerable communities and the rest of the actors (Nelson and Jenkins, 2006). However, studies on social entrepreneurship for energy poverty and structured interventions are very rarely found in the literature (Bouzarovski and Petrova, 2015). More research on energy poverty via human-centred studies, energy justice, innovation, incentives, interventions, and policies has been suggested (Jenkins et al., 2018; Sovacool, 2014; Sovacool and Dworkin, 2015).

Given the different literature strands in the paper, Table I (Theoretical framework) lists the basic tenets of the literature.

\section{[INSERT TABLE I AROUND HERE]}

Social entrepreneurship as part of entrepreneurship theory is a consolidated field; however, its positioning as a relevant actor in sustainable development is not yet as well 
consolidated (Mair and Marti, 2006). There is no universally accepted definition for social entrepreneurship. However, its mission regarding disadvantaged groups and systematic transformations seems to be accepted (Okkonen and Lehtonen, 2016). Social entrepreneurs use networks to obtain resources and legitimacy differently than conventional commercial enterprises (Littlewood and Khan, 2018). These more effective social management strategies applied to social intrapreneurship within corporations could catalyse socially innovative activities in energy poverty.

This paper also acknowledges the criticism of social entrepreneurship, one, as a vehicle for neoliberalism to cover the wounds created by capitalism, particularly when social entrepreneurs aim to provide public services corresponding to the State (Nicholls and Teasdale, 2017). It also recognises the scepticism regarding social enterprises' ability to serve the public good (Dey et al., 2016) in response to the need to balance market and social service logic. However, the growth of social entrepreneurship as a multilevel approach (Geels, 2002) may facilitate the expansion of social entrepreneurship ideas in all actors, guiding and enriching policy makers' views. Instead of the social entrepreneur being a substitute for the state in the provision of social services, close collaboration could be achieved with the integration of the new and old logics (Dey et al., 2016). From this perspective, social entrepreneurship could be in a good position to approach social problems (Dacin et al., 2011) if their logic is integrated within corporations. Niches (such as social intrapreneurship) that are more able to impact the dominant logics are the ones that are intermediately placed. They can bridge actors and are neither overly radical nor too akin to energy companies (Smith, 2007).

The literature on social entrepreneurship and social intrapreneurship is connected. Social intrapreneurship is social entrepreneurship that occurs within existing rather than start-up 
organisations (Halme et al., 2010). Social entrepreneurship is the establishment of initiatives to implement social innovations within organisations (Nandan et al., 2015; Summers and Dyck, 2011). Considering the synergies among these three concepts, we focus on the role of social intrapreneurship in tackling energy poverty within energy corporations. The social intrapreneurship literature emphasises goal alignment and embeddedness, which imply unique attributes for alleviating poverty, but it also considers how the organisational structure influences the effect of social intrapreneruship and how can be instrumental in organisational change (Kistruck and Beamish, 2010).

Organisational change theory includes strategies and techniques for planned changes to alter the behaviours of the members of an organisation. Organisational change researchers are concerned with how the exercise of agency of different actors influences the rhythm of change (Weick and Quinn, 1999). SED would be a planned episodic change to initially affect the scope of a department by approaching vulnerable consumers within an adaptative organisation that would eventually develop into a continuous, long-term process of change to slowly spread the new logics.

The perception of the structure of internal divisions of social intrapreneurship has received little attention, although social intrapreneurs show unique benefits in the alleviation of poverty (Kistruck and Beamish, 2010). Separate departments may be appropriate to bring together different actors with boundary spanning roles (Berkes, 2009; Leifer and Delbecq, 1978).

Stakeholder theory (Mitchell et al., 1997; Parmar et al., 2010) may be used to analyse the dynamic adaptation of large-scale companies in the context of energy poverty and just energy transitions. Managers prioritise stakeholders according to their power, legitimacy, and urgency (Agle et al., 1999). Drawing from Barnett (2019) firm's actions to help society may be self- 
sacrifice, costly, proactive, sustained and not promoted. The management of secondary stakeholders may be reconciled with effects on primary stakeholders' relations. The consideration of vulnerable consumers as priority stakeholders would be an integral part of the stakeholder approach of this paper. An external stakeholder issue such as energy poverty may be internalized as a company-owned issue and even a strategic activity generating more commitment (Winn, 2001). Jenkins et al. (2020) point out that energy justice and reflexivity have a role in supporting legal restructuring and new financing models in utilities.

CSR scholars argue that CSR needs to be reshaped to work for society and not only for corporations (Margolis and Walsh, 2003). Vulnerable customers may depend entirely on energy companies to obtain the energy services that would allow them to develop their primary capabilities (Day et al., 2016), but those are problems that lack the push of legitimate stakeholders (Barnett, 2019). In addition, CSR does not affect all levels and all stakeholders of the organisation in the case of large-scale companies (Frankental, 2001). Bringing social intrapreneurship into business-as-usual may contribute to enriching corporate practices towards vulnerable customers while simultaneously providing a more advanced stakeholder culture (Maon et al., 2010).

Organisational theory is concerned with the question of what managers pay attention to and what management's responsibility is towards an inclusive stakeholder orientation (Agle et al., 1999; Chandra, 2019; Parmar et al., 2010). Moreover, the obsession of Suddaby et al. (2017) with enhancing the construct clarity sheds light on understanding the legitimacy approach of this study. Legitimacy is a multilevel social process that fluctuates between the perceptions of the evaluators of their actions and the salience of social intrapreneurship to change the positions of vulnerable communities in the stakeholder's map (Halme et al., 2010). How to alter corporation 
practices towards forgotten stakeholders may be obtained through further exploration using the stakeholder's lens (Agle et al., 1999). Any organisational change within corporations involves the understanding of the dynamics of power and social intrapreneurship, which may increase salience through innovation and transformative acts (Avelino and Rotmans, 2009).

The transition context may foster the strategic creation of social intrapreneurship departments devoted to tackling the social problems of weaker stakeholders. The relative importance of the intermediary departments varies from context to context. Avelino and Rotmans (2009) have already considered combinations of organisational studies of nonlinear processes of structural change in societal systems.

Organisational change theory focuses on the interactions of structures, actors, and practices. To understand the role of social intrapreneurship within corporations, it is important to understand the interplay between social innovation spaces in energy companies (Hess, 2018). The length of time for this evolution may be substantial, perhaps as long as a decade. Transitions may serve to accelerate the tempo and rhythms of change (Weick and Quinn, 1999) and the need for a change in the logic of the company actors. Some researchers have explored the agency of social intrapreneurship in just energy transitions, although less attention has been paid to specific aspects in the context of the energy poverty problem (Nandan et al., 2015).

The innovation spaces of social intrapreneurship are disruptive protected areas where social innovators may begin the process of systemic change (van Tulder, 2018). The discussion regarding the logic of small companies entering large companies and, thus, developing a proactive role in green entrepreneurship has already been addressed by Hockerts and Wüstenhagen (2010). This paper focused on defending social intrapreneurship as a means to tackle energy poverty in large-scale energy corporations. An apparently minor change in the 
organisational structure of a large-scale energy company may change its stakeholder map and allow the integration of a new external logic into the organisation. Such integration could facilitate slow transformation from inside corporations without radically changing their own business model and could also accelerate the adaptation of the incumbents to a just energy transition (Loorbach and Wijsman, 2013).

The context of just energy transitions will lay the foundation for the problem of energy poverty and the vulnerability of energy rights (Jenkins et al., 2018). Therefore, in the transition literature, conversations about the agency of niche actors as social intrapreneurs and their interaction within incumbent energy companies stand out. This study, however, prefers to consider transitions as a contextual framework to be investigated in the organisational model of SED rather than considering it the objective of this research.

The proposed conceptual model is organised as follows. The first part addresses the micro-level approach of the mission and the salience of stakeholders, change agents and evaluators (Sections 1 to 3 ). These three sections respond to the conceptual foundations of the proposed model to tackle energy poverty. Moreover, the meso-level approach of organisational changes affecting stakeholder theory may justify the creation of a bridging and boundary department of social intrapreneurs within the energy company (SED) (Section 4). The remainder of this article is organised as follows: in Section 4.1, we explore the impact of the integration of the social mission and the higher salience of social intrapreneurs on energy actors. Section 4.2 addresses the continuous balance between social and commercial resources. Section 4.3 addresses the energy justice principles to be implemented in the energy company. Section 4.4 introduces the formation of a department of social intrapreneurship geared towards energy poverty and the factors affecting the organisational change in the stakeholder map. In the 
Discussion section, we argue that this proposal may help in a just energy transition and mitigate energy poverty. We also identify some limitations, practical implications, and a research agenda and, finally, offer some conclusions.

\section{From a niche of social intrapreneurship in energy poverty to the regime of energy companies}

The Social Entrepreneurship Department (SED), which is formed by social intrapreneurs, may be designed to reduce the number of vulnerable consumers, while acknowledging the complexities of energy poverty. Large-scale energy companies refer to commercialization companies, energy service suppliers, and energy companies' transmission and/or distribution companies in the electricity system. The department may be located close to the CEO and leaders, separated from the rest of the corporate departments but integrated into all of them. Although this model could be applicable to sectors other than energy (such as water, real estate, food, health), this proposal focuses on the energy sector.

\subsection{The social mission and the unique attributes of social intrapreneurs to minimise energy poverty}

First, the organisational change process should be guided by a clear social goal for the new department of social intrapreneurs to tackle energy poverty, which may be directly linked to the core business (Dacin et al., 2011). Energy companies have already supported external social entrepreneurs, but they have not included the mission of reducing energy poverty into their organisational structure. Such a departmental mission may legitimize the use of corporate 
resources, thus taking a further step towards mitigating energy poverty through a proactive role (Turnheim and Sovacool, 2019). A joint vision of energy poverty may link actors with different objectives (Berkes, 2009).

Managerial perceptions of marginal stakeholders are frequently avoided at the core of energy corporations. SED may face resistance, inertia, and legitimacy threats from managers (Halme et al., 2010; Summers and Dyck, 2011). Therefore, respect and tolerance would be the first step towards continuous cultural change and value alignment (Kistruck and Beamish, 2010; Weick and Quinn, 1999). Social entrepreneurs may increase vulnerable communities' salience as perceived by managers due to the unique attributes of social entrepreneurs as agents of change (Agle et al., 1999). The level of salience may depend on managers' perceptions of the following three attributes of social intrapreneurs and communities:

Power would be required to mobilise resources for a mission whose logic is contradictory to the profit-dominant logic. Any organisational change within corporations involves the understanding of the dynamics of power (Avelino and Rotmans, 2009). Social intrapreneurs might not be powerful actors, but they may be actors who exercise a different type of power, such as innovative and transformative power. Additionally, the perceived "marginal" reciprocal power of social entrepreneurs may enable agency and empowerment of the communities. In a space of innovation and nonconformity such as SED, social intrapreneurs might exercise socially innovative power, and in the interaction with managers, they might exercise transformative power (Avelino and Rotmans, 2009). Beyond that, social entrepreneurs may reciprocally empower vulnerable communities to ensure that such communities control and use those resources for their own benefit (Pareja-Cano et al., 2020). 
The legitimacy of social intrapreneurs and communities may be pragmatic, moral, and cognitive. At this initial stage of organisational change, the process of acquiring moral legitimacy is viewed as a dynamic process of action that is supported by a sense of justice that upholds the moral rights of vulnerable customers who are considered increasingly essential to society (Suddaby et al., 2017). These weak stakeholders may eventually become direct clients. The increasing visibility of energy poverty may create grounds to build the moral legitimacy of the vulnerable customers and the social intrapreneurs whose activity is devoted to these groups. Social intrapreneurs are perceived as morally self-legitimised and having other-regarding focus and values. Their perceived legitimacy may influence the dominant actors and topics, which is important for the survival of social intrapreneurship (Nicholls, 2010). This perceived legitimacy will fluctuate over time, adapting to the perception of the energy poverty problem and to the valuation and assumption of co-responsibility by the leaders of the organisation. Social intrapreneurs in boundary roles may be responsible for changing the perceptions of managers (Leifer and Delbecq, 1978).

The cultural and network embeddedness of managers may encourage moral legitimacy in a separate department of social intrapreneurs (Dart, 2004; Kistruck and Beamish, 2010), whose agency within the SED may, in turn, increase such legitimacy (Weick and Quinn, 1999). The social intrapreneurs forming the SED may slowly transform the perceived legitimacy of vulnerable customers. They are more likely to be formalised when organisational decisionmakers explicitly recognise crucial problems, such as energy poverty (Aldrich and Herker, 1977).

Urgency is revealed through the emergency or structural situation of vulnerable customers who may need immediate action to be connected to the grid or to provide them with standard, minimum household conditions. The embeddedness and understanding of social 
problems by social intrapreneurs bring the company's attention to the typically unattended vulnerable customers (Agle et al., 1999). Local embeddedness is required to leverage resources. Additionally, social enterprises are dynamic, empowering organisations that are contextually grounded in the concerns of the community (Dey and Steyaert, 2010).

Close to the CEO, social intrapreneurs who are in boundary roles may become more reliable vis-à-vis other units considering that their leaders decide who is inside and who is outside the boundary within the organisation. Decision makers may recognise the contingencies of the energy poverty problem, and the SED would serve as a buffer and intermediary group. The organisational change process will start with empowered leaders facilitating the change (Weick and Quinn, 1999). Leaders may provide organisational support, recognition, communication, and tolerance of the "extraordinary" agency of social intrapreneurs (Halme et al., 2010). Our model argues that the context of energy justice and a just energy transition may grant legitimacy to influence such perceptions.

The new logic may reorient the power relations among stakeholders towards the aspirational mission (Winn, 2001). Social intrapreneurs may try to disseminate their approach within the organisation to ensure that primary and secondary individuals have equal positions and recognise the mission of SED (Agle et al., 1999; Parmar et al., 2010). To understand the motivations behind building social engagement, it is useful to analyse the internal and external aspects of larger companies (Brown et al., 2010). The SDG framework could also provide advantages for corporations supporting a real inside-outside transformation in the mission of energy companies, considering the nonbinding nature of the SDG (Biermann et al., 2017).

\subsection{The balance between the economic and social missions to achieve self-sustainability}


In social entrepreneurship, profit is a means to an end rather than an end in itself (Mair and Marti, 2006). Social intrapreneurs within a corporation may suffer from tension when pursuing social and economic objectives. However, a bridging department may provide a way of managing this dual tension (Kistruck and Beamish, 2010). The SED may experience obstacles, such as claims of short-term profit loss, uncertainty, and lack of expertise, in dealing with social issues within the organisation. Tension due to pursuing social good through business means may emerge, and hybrid profiles may be required for such complex tasks (Halme et al., 2010). This proposal argues that the new logic would seek to generate social impact as a priority; however, economic profit would also be a requirement to guarantee a self-sustainable model. The hybrid spectrum presented by Alter (2007) could help to move the social intrapreneurship logic to an energy corporation that currently operates under a for-profit model. Such organisational change may potentially affect the whole design of the company organisation in the long run, since changes may have relevant implications for the stakeholder map (Waddock et al., 2015; Winn, 2001). Thus, this model challenges a more comprehensive performance of financial and nonfinancial information in relation to energy vulnerability, where the conflict of less examined antagonistic logics is replaced by interaction. Additionally, organisations with social goals require strategic information from external stakeholders (Leifer and Delbecq, 1978).

First, the guarantee of income generation might allow SEDs to be self-sustaining over time (Alter, 2007), although their social mission would continue to be the priority. Sophisticated and thoughtful solutions would accompany a transformation pathway, and the resistance of social intrapreneurs to tensions in the social and economic arenas would prevail. The SED activities may be directed to community empowerment or energy efficiency in the field of housing but must always be in line with the mission of tackling energy poverty, which is fully 
related to the electricity supply business. Inclusivity would not be reduced to solely providing cheaper products or services to vulnerable customers but would also be extended to the whole energy system (van Tulder, 2018).

Second, to illustrate our proposal, all consumers considered vulnerable would be easily identified by the energy company as consumers entitled to the electricity social tariff or a nonpayment situation. The SED focus would be limited to the vulnerable customers of the company (not from other energy companies). Being arrears in utility bills would be only one of the indicators of energy poverty, which provides a partial approach to the problem in the initial phase of SED implementation. However, the difficulty inherent in identifying hidden energy poverty and the link between poverty and energy poverty may always be present in SEDs (Cools and Oosterlynck, 2015). These departments carefully review the situation of each vulnerable customer and the social costs to understand social value creation (Chandra, 2019). Social business experts could design interventions for these vulnerable customers on a case-by-case basis.

Companies and vulnerable consumers could benefit from these interventions, since if fewer consumers are vulnerable after SED intervention (i) the company would obtain a financial (and nonfinancial) gain because more bills would be paid and (ii) the vulnerable consumers would become less poor and more reliable (Cools and Oosterlynck, 2015).

Third, a great deal of literature has been devoted to exploring the role of large companies in low-income markets and access to energy, but surprisingly little research has been devoted to corporations with customers facing energy poverty in developed countries (Van Zanten and Van Tulder, 2018). The reason for the lack of research on energy poverty in developed countries is not clear (Bouzarovski and Simcock, 2017). However, the reasons may be that the market of 
vulnerable people may not seem large enough to be perceived as having enough purchasing power or that the fear of stigmatization and social exclusion is higher in developed societies.

Corporate finance departments could operate in the impact finance markets of the new social activities and even on the access to impact investment, which may be regarded as a competitive advantage (Schoenmaker, 2017). Social intrapreneurship is based more on collaboration and interaction than on competition. However, if all companies follow the same social strategy, this could contribute to tackling energy poverty and could be a competitive advantage for the company that first implements it, which could become a Pioneer Goliath with a larger scope and a long-term orientation (Hockerts and Wüstenhagen, 2010). Large-scale change is perceived as counterintuitive within the company, so for prime movers, the size and participation of communities tend to be unrelated challenges to abandoning the assumption of tension between the opposing social and economic blocks, which would thereby facilitate the interaction of the logic of social intrapreneurs (Weick and Quinn, 1999).

\subsection{Energy justice principles to legitimise organisational change}

Energy justice is the application of the criteria of justice to energy policy, energy production systems, energy activism, energy security and climate change (Jenkins et al., 2018). This section includes the theoretical framework that could foster the perception of moral legitimation of this change. The social context of energy justice in a corporation may be a factor that increases the salience of vulnerable communities. More agency against energy poverty may become socially demanded (Campos and Marín-González, 2020). 
Energy justice may help to develop the framing of social intrapreneurship with a strong resonance on a wide variety of actors (Hervieux and Voltan, 2018). This article does not intend to position energy poverty as a problem to be fully resolved by assuming a positivist discourse that understands social dysfunctions as inefficiencies solvable through good technical management. Energy poverty affects the people who suffer from it, and energy justice requires reflexivity to impact the work of energy companies (Jenkins et al., 2020). Therefore, this brings the debate to a less reductionist dimension.

The previous work has analysed organisational theories from the standpoint of equating the power of the different stakeholders (Burga and Rezania, 2016; Margolis and Walsh, 2003). However, the current structures, such as CSR, are receiving criticism, and alternatives that increase the impact of corporations and their sustainability commitment are needed (Fineman and Clarke, 1996; Frankental, 2001). This proposal argues that energy justice could inform decisions to realign values, balance power among stakeholders, and legitimize the most vulnerable people (Mitchell et al., 1997).

Energy companies may interiorise the energy justice framework as a valid tool to guide decision-making through the energy system (Sovacool et al., 2017). This study follows the definition of energy poverty proposed by Day et al. (2016) because it is global and fits the energy justice principles.

SEDs may define vulnerable customers as all the consumers of the energy company that could be entitled to the social tariff ("vulnerable consumers"). In relation to the triple bottom-line approach, we found that the eco-vision seemed to be more accepted in practice (Fineman and Clarke, 1996; Hockerts and Wüstenhagen, 2010) but that the inclusion of vulnerable groups in the company business was less explicit. 
SED leaders may head the application of the energy justice principles framework by promoting availability, affordability, due process, good governance, sustainability, intergenerational equity, intragenerational equity, and responsibility (Hiteva and Sovacool, 2017; Jenkins et al., 2018; Sovacool and Dworkin, 2015).

Finally, this study argues that the implementation of energy justice may stimulate employee motivation and talent retention. Employees may participate in social intrapreneurship programmes to overcome the internal challenges faced by the SED in tackling energy poverty. In the same way that NGOs train their staff in financial management, SEDs would train their social intrapreneurs towards a more user-friendly or human-centred approach and dynamic cocreation business relationship (Brugmann and Prahalad, 2007). An exchange of hybrid and complementary skills may be appreciated when dealing with vulnerable groups (Turnheim and Sovacool, 2019).

\subsection{The impact of social intrapreneurship on the stakeholder map}

This section focuses on how the formation of a bridging department of social intrapreneurs within an energy company illustrates a process model of an organisational experiment to deal directly with vulnerable customers. The Social Energy Department (or SED) would be an inclusive innovative approach in the energy company (Halme et al., 2012) implemented by the logic that social intrapreneurs may gradually transform energy organisations (Wesseling et al., 2020).

Energy companies cannot live in isolation, removed from energy poverty. An SED could be a direct link to vulnerable customers. Social intrapreneurs may act as change agents in their 
decentralised unit (Weick and Quinn, 1999). Isolating SED from existing CSR or sustainability departments may reinforce the attention and salience of vulnerable customers. CSR departments do not generally have a perceived single identifiable mission and are normally associated with unclear purposes. The CSR department may not be working to reduce energy poverty since it was not its original purpose. The same explanations may apply to environmental departments (Berkes, 2009). Classic bureaucratic mechanisms responding to rigid corporate reporting requirements frequently hinder the CSR department from fulfilling the company's responsibility towards weaker stakeholders. The typical problems of vulnerable customers, such as high prices or the impossibility of paying electricity debts, are not shown respect and are not duly addressed by corporations.

The clear mission of this specific project department would make it more agile, enabling it to motivate a team of social intrapreneurs who are well aware of the intricacies of the company to solve challenges. Formal interunits of social intrapreneurs may provide protected nonbureaucratic mechanisms on the fringe of the organisation that may regulate the flow of information regarding vulnerable customer needs (Berkes, 2009; Kistruck and Beamish, 2010). This separation and focus may better overcome cultural constraints, network embeddedness (Berkes, 2009; Halme et al., 2010) and management deficiencies when dealing with weaker stakeholders in the dominant practice of stakeholder management. A confident, unidirectional network based on mutual trust may focus its attention on a singular objective, i.e., energy poverty, thereby conveying a credible message and avoiding confusion among profit and nonprofit logic. Separation may also build on the shift in the mindset of leaders (Kistruck and Beamish, 2010). 
Second, SEDs may adopt social business models, such as the low-income customer model, with vulnerable consumers as their target customers and may potentially revise the electricity tariff and other services especially designed for them. Vulnerable customers should be treated as special, priority customers who may be supervised by social workers (Cools and Oosterlynck, 2015). Income generation in SEDs would not originate in vulnerable customers alone (Cools and Oosterlynck, 2015). Areas and activities that may be relevant to this department could be the following: the implementation of appropriate metrics for measurement and identification of vulnerable homes (Boerenfijn et al., 2018; Dineen et al., 2015), energy scans, consumption behaviour or empowering processes, energy efficiency in houses and appliances and house retrofitting, pre-financing models for energy appliances (Cools and Oosterlynck, 2015), and supplier credits for energy efficiency (Santamouris, 2016) or affordability of energy prices (Jenkins et al., 2018).

Third, stakeholder theory also focuses on the management of the relationships among them. Such relationships may be modified to reinforce the salience of weaker stakeholders (Agle et al., 1999; Kistruck and Beamish, 2010). Therefore, the following boundary conditions to be pursued in the relationship among stakeholders may explain the potential institutionalization of SED initiatives.

First, SEDs may directly foster reciprocal empowerment to vulnerable consumers by considering them "special clients", thereby achieving legitimation and attention from social intrapreneurs and leaders and a new status of primary stakeholder to transact with the company (Barnett, 2019). The empowerment of marginalised communities may become problematic, and cooperative building tactics, such as physical presence and regular contacts, may be appropriate. 
The equation regarding the power of vulnerable consumers to other customers may affect the energy company's behaviour (Mitchell et al., 1997).

Second, NGOs and social entrepreneurs may become strategic providers of the department thanks to their unique capabilities to deal with vulnerable communities. Instead of providing services only to a few households they could support the relationship with all the vulnerable consumers of the company. Immediate responses are possible because of the proximity and social expertise of intrapreneurs (Aldrich and Herker, 1977; Berkes, 2009).

Third, asymmetry of information is one of the major limitations in energy poverty in a complex energy system that requires greater knowledge from all actors (Broberg and Kazukauskas, 2015; Sovacool, 2014). The information from weaker stakeholders would naturally be perceived as non-interesting by the company. The use of liaison roles to adequately transmit and filter reciprocal information in an understandable language and to represent the company may preserve balance and increase salience (Keszey, 2018).

Fourth, the routinization of the activity is a great challenge. Social intrapreneurs may bring special clients into the organisation. By identifying a household in energy poverty, the SED would provide the company with a situation to address. Once the activities and how to deal with them are clear, the tasks could be routinised, and the difficult work at hand organised on a caseby-case basis.

Comanagement of social intrapreneurs with vulnerable communities may contribute knowledge and capabilities that are acquired at different levels. Robust bridges need to be built for the success of this organisational experiment (Berkes, 2009). Another factor would be to increase the use of networks rather than the traditional use of individual members of the organisation (Halme et al., 2010). In relation to the development of stakeholder theory, the 
proposal would involve some relevant transformations through the stakeholder map by way of organisational change, including a social intrapreneurship department geared towards energy poverty (Fineman and Clarke, 1996). According to Winn (2001, p. 160), "stakeholder theory may shed light on what circumstances change such powers".

To illustrate the impact of our model on the stakeholder map, Figure 1 displays how less powerful stakeholders (NGOs, vulnerable customers) may equate to and become powerful stakeholders (nonvulnerable customers, creditors, and employees) after the entry of a bridging department, such as an SED, into the organisation. This change may affect the relationships among all stakeholders and gradually transform the perspectives of traditional departments. This different perspective may create uncertainty until the SED is consolidated while coevolving with the rest of the players until the design of the new organisational structure is positively adopted (Geels and Schot, 2007; Van Tulder and Keen, 2018).

\section{[INSERT FIGURE 1 AROUND HERE]}

NGOs and social entrepreneurs move from being external stakeholders to becoming direct suppliers of capabilities-centred services aimed at providing better services to vulnerable customers. It would be more than a bilateral NGO-firm partnership (Van Tulder and Keen, 2018). Social agents might become bridges to the human-centred approach that is missing in energy companies. Vulnerable customers may want to continue seeking mediation from social groups, such as NGOs, social entrepreneurs, and social workers (Aldrich and Herker, 1977).

In relation to energy regulators, SEDs may provide more informed policy insights into energy poverty (Geels, 2004) because energy poverty may become a real issue for more actors. Gradually, there may be an increase in binding regulation in the field of energy poverty (Van Zanten and Van Tulder, 2018). 
Traditional consumers might be more aware of the situation of their vulnerable counterparts thanks to the targeted communication of SEDs and vulnerable consumers, who were previously considered 'guilty' of non-payment, would become salient customers. Constant customer feedback would be required to be aligned with a participative approach (Van Tulder and Keen, 2018).

New financial entities may be interested in this model. Impact investors and venture philanthropy organisations may finance this new social intrapreneurship activity (Frankeltan, 2001). Sustainability finance is a growing sector that may be keen to work with corporations in the implementation of its instruments (Schoenmaker, 2017).

This managerial challenge may require senior leadership with social and business skills (Brugmann and Prahalad, 2007), and profiles from NGOs could provide SEDs with humancentred skills. Moreover, social engagement, social intrapreneurship and open social innovation could be launched by SEDs to attract internal and external projects for vulnerable consumers (Chesbrough and Di Minin, 2014).

Finally, the organisational culture of the energy company may be transformed (Maon et al., 2010; Waddock et al., 2015). SED managers may take responsibility and undertake and disseminate the social mission in their daily activities. They would become the contact people for vulnerable stakeholders. Over the past few decades, managers have encouraged environmentally friendly practices in business (Fineman and Clarke, 1996). Therefore, they should also encourage social practices aimed at tackling energy poverty. SEDs could encourage the social awareness of vulnerable customers through a stronger social intrapreneurship presence in the company (Nelson and Jenkins, 2006). 


\section{Discussion and future research}

Current corporate structures in energy companies do not contribute to minimising energy poverty and are sometimes even accused of perpetuating it (Campos and Marín-González, 2020). This may be mainly due to the limitations of conventional CSR approaches to focus on social problems and, in particular, vulnerable stakeholders. Social intrapreneurship may lead to a step forward in stakeholder management of vulnerable customers of energy companies in inclusive transitions. Slow transformation pathways would allow the basic elements of the energy companies to remain untouched, which may be more realistic (Geels and Schot, 2007).

Our research addresses energy poverty from the lens of social intrapreneurship to contribute to an organisational problem (specifically in the field of management of vulnerable stakeholders) in the context of energy poverty. This four-component process model (social intrapreneurship, social priority, legitimation through energy justice and the bridging structure) may be a topic of great theoretical and practical interest. The main contribution of this paper is provided at the nexus of organisational change, social intrapreneurship and just energy transitions. The integration of the logic of social entrepreneurship from the perspective of a bridging department may foster the salience of social intrapreneurship and purpose driven logic in the energy sector.

First, this model focuses on the micro-level evolution of the salience of vulnerable customers and social intrapreneurs as change actors, as perceived and evaluated by the leaders of energy corporations. Social intrapreneurs are more suitable for dealing with vulnerable customers that are naturally peripherical to the company, but they both need legitimation. Energy justice could be a crucial factor in enhancing the perception of moral legitimation of vulnerable communities and SED departments in the context of a just transition (Suddaby et al., 2017). The 
role of the agency of company actors in energy poverty is fostered by proactive and social intrapreneurs that may create spaces for developing the social focus to expand the logics that are naturally opposed by the company.

Second, stakeholder theory can be contributed to on the meso-level, including the formation of bridge and boundary departments established to deal with marginal communities and to increase the salience of weaker stakeholders. The forming of bridging departments in corporations to address secondary stakeholders' main problems could be further explored in the context of just transitions.

This organisational movement may enable multiple changes on different levels over time. Practitioners may apply complex thinking during the organisational change process, not only in the early phases but also throughout this process since the points of view of the different stakeholders may change constantly (Mitchell et al., 1997).

Regarding the temporality of just energy transitions, the organisational change process could be accelerated considering the crucial role of energy companies as influential actors (Loorbach and Wijsman, 2013), but the expansion of social intrapreneurship into the dominant system may also encourage its transformation (Wesseling et al., 2020). As Waddock et al. (2015) indicated, social intrapreneurs may become attractors that transform energy companies to further contribute to sustainable development. SEDs could act as a bridge between the organisational inertia of energy companies and the vulnerable customers of these companies. Another main objective of this proposal is to avoid the risk of social intrapreneurship remaining a marginal movement in the organisation that is guided by other logics or interests that do not include vulnerable stakeholders as a central part of its business model (van Tulder, 2018). 
Our research has several limitations, such as remaining contextualised. However, contextualisation is assumed to be essential to social construction (Winn, 2001). The model focuses on the perceptions of subjective leaders whose perceptions might be distorted. The insights of this theoretical study could be richer if more empirical tests are performed in the context of energy poverty, which could be applied conceptually to corporations in other sectors in relation to SDG activities and subject to the corresponding critical assessments (Van Zanten and Van Tulder, 2018).

This proposal could therefore be tested to create knowledge through case studies with specific initiatives that have been put into practice through similar formats (even if it is within CSR departments) or for other vulnerability problems. We explicitly reflect on the cautiousness of our statements since they deal with vulnerable groups and the difficulty of managing the different interests at stake.

As a summary, our study suggests several theoretical and practical contributions and implications for scholars, intrapreneurs and leaders, which are reflected in Table II (Theoretical and practical contributions) below.

\section{[INSERT TABLE II AROUND HERE]}

This conceptual paper has some practical implications. A new social strategy is suggested for developing interorganisational social business relationships in just energy transitions. This proposal could be implemented as an organisational process experiment with transforming potential (Rotmans and Loorbach, 2009; Summers and Dyck, 2011) and would require high levels of responsibility and respect towards social needs for it to be correctly implemented in both theory and practice (Ghoshal, 2005). Social entrepreneurship has a proximity to energy poverty that may not be so easily transferable to larger structures, such as corporations. What 
appears to be a small organisational change could have a major impact in the electricity system (Waddock et al., 2015).

This study suggests several lines of research. First, more research on strategic niche management, multi-stakeholder partnerships and transformative innovations in the energy system involving co-management or multi-actor partnerships is needed. Attention may be paid to internal processes within business actors (such as reciprocal social learning, iterative feedback, networking, or visioning). Second, further investigation into social intrapreneurship development within corporations aimed towards sustainability and empirical evidence to prove solidity, sustainability, and resilience to the proposed model are needed.

Furthermore, research into sustainable finance may provide alternatives to the apparent lack of availability of massive private funds to mitigate energy poverty (Martiskainen et al., 2018). Finally, future research could examine the adaptation of bridging departments to diverse political, social, or economic contexts, which will make the department's priorities vary depending on the types of vulnerability. As an example, bridging departments in developing countries subject to the corresponding adaptation could provide energy access in remote areas without access to an electricity grid (the Last Mile Department).

\section{Conclusions}

Corporate proposals to solve energy poverty are limited, although the relevance of this social problem is increasing in political agendas. Vulnerable energy customers remain at the periphery of the stakeholder map of energy companies. Energy poverty mitigation requires the coordinated participation of multiple interrelated actors, and in particular, energy businesses seem to have an 
opportunity to rethink their approaches and contribute to the eradication of energy poverty in the transition to just energy.

This process model proposal intends to fully integrate the logic of social intrapreneurship in bridging departments that may increase the salience of vulnerable customers to large-scale energy companies. Social intrapreneurship in energy poverty could proactively achieve a higher position within energy companies (Geels, 2002).

Energy companies could take advantage of the social intrapreneurship model to focus on what should matter in the just energy transition, including all actors, while simultaneously upholding both economic profit and the social mission. Thus, energy companies could lead the demand for social inclusivity in the electricity sector and coparticipate in the change towards sustainable development by steering all actors, including regulators and investors, towards social business practices. The inclusion of bridging departments of social intrapreneurs within energy companies could be implemented in other sectors and might help corporations approach the SDGs.

A true willingness to change is required for the private sector to respond differently to the social demands of the transition to just energy. 


\section{References}

Agle, B.R., Mitchell, R.K. and Sonnenfeld, J.A. (1999), "Who matters to CEOs? An investigation of stakeholder attributes and salience, corporate performance, and CEO values", The Academy of Management Journal, Vol. 42 No. 5, pp. 507-525.

Aldrich, H. and Herker, D. (1977), "Boundary spanning roles and organization structure", The Academy of Management Review, Vol. 2 No. 2, pp. 217-230.

Alter, K. (2007), "Social enterprise typology", Virtue Ventures LLC, Vol. 12 No. 1, pp. 1-124.

Araújo, K. (2014), "The emerging field of energy transitions: progress, challenges, and opportunities", Energy Research \& Social Science, Vol. 1, pp. 112-121.

Avelino, F. and Rotmans, J. (2009), "Power in transition: an interdisciplinary framework to study power in relation to structural change", European Journal of Social Theory, Vol. 12 No. 4, pp. 543-569.

Barnett, M.L. (2019), "The business case for corporate social responsibility: a critique and an indirect path forward", Business \& Society, Vol. 58 No. 1, pp. 167-190.

Berkes, F. (2009), "Evolution of co-management: role of knowledge generation, bridging organizations and social learning", Journal of Environmental Management, Vol. 90 No. 5, pp. 1692-1702.

Biermann, F., Kanie, N. and Kim, R.E. (2017), "Global governance by goal-setting: the novel approach of the UN Sustainable Development Goals", Current Opinion in Environmental Sustainability, Vol. 26, pp. 26-31.

Boardman, B. (1991), Fuel Poverty: From Cold Homes to Affordable Warmth, Pinter Pub Limited, London, New York. 
Boerenfijn, P., Kazak, J., Schellen, L. and Van Hoof, J. (2018), "A multi-case study of innovations in energy performance of social housing for older adults in the Netherlands", Energy and Buildings, Vol. 158, pp. 1762-1769.

Boni, A., Leivas, M., De La Fuente, T. and Belda-Miquel, S. (2016), "Grassroots innovation for human development: exploring the potential of participatory video", International Journal of E-Politics, Vol. 7 No. 4, pp. 26-39.

Bouzarovski, S. and Petrova, S. (2015), "A global perspective on domestic energy deprivation: overcoming the energy poverty-fuel poverty binary", Energy Research \& Social Science, Vol. 10, pp. 31-40.

Bouzarovski, S., Petrova, S. and Sarlamanov, R. (2012), "Energy poverty policies in the EU: a critical perspective", Energy Policy, Vol. 49, pp. 76-82.

Bouzarovski, S. and Simcock, N. (2017), "Spatializing energy justice", Energy Policy, Vol. 107, pp. 640-648.

Broberg, T. and Kazukauskas, A. (2015), "Inefficiencies in residential use of energy — a critical overview of literature and energy efficiency policies in the EU", International Review of Environmental and Resource Economics, Vol. 8 No. 2, pp. 225-279.

Brown, D.L., Vetterlein, A. and Roemer-Mahler, A. (2010), "Theorizing transnational corporations as social actors: an analysis of corporate motivations", Business and Politics, Vol. 12 No. 1, pp. 1-37.

Brugmann, J. and Prahalad, C.K. (2007), "Cocreating business's new social compact", Harvard Business Review, Vol. 85 No. 2, p. 80.

Burga, R. and Rezania, D. (2016), "Stakeholder theory in social entrepreneurship: a descriptive case study", Journal of Global Entrepreneurship Research, Vol. 6 No. 1, p. 4. 
Campos, I. and Marín-González, E. (2020), "People in transitions: energy citizenship, prosumerism and social movements in Europe", Energy Research \& Social Science, Vol. 69, p. 101718.

Chandra, Y. (2019), "Whose value? Problems in valuing social enterprise and research implications", Social Enterprise Journal, Vol. 15 No. 2, pp. 233-242.

Chesbrough, H. and Di Minin, A. (2014), "Open social innovation", New Frontiers in Open Innovation, Vol. 16, pp. 301-315.

Cools, P. and Oosterlynck, S. (2015), Energy Poverty and Social Entrepreneurship: Strengthening Pre-Financing Models for Energy Efficient Electrical Appliances Through The" Energy for All" Programme, Improve Case Study N 13, Herman Deleeck Centre for Social Policy - University of Antwerp, Antwerp.

Dacin, M.T., Dacin, P.A. and Tracey, P. (2011), "Social entrepreneurship: a critique and future directions", Organization science, Vol. 22 No. 5, pp. 1203-1213.

Dart, R. (2004), "The legitimacy of social enterprise", Nonprofit Management and Leadership, Vol. 14 No. 4, pp. 411-424.

Day, R., Walker, G. and Simcock, N. (2016), "Conceptualising energy use and energy poverty using a capabilities framework", Energy Policy, Vol. 93, pp. 255-264.

Dey, P., Marti, L., Teasdale, S., \& Seanor, P. (2016). Alternative enterprises, rhythms and (post) capitalism: Mapping spatio-temporal practices of reproduction, escape and intervention.

Dey, P. and Steyaert, C. (2010), "The politics of narrating social entrepreneurship", Journal of Enterprising Communities: People and Places in the Global Economy, Vol. 4 No. 1, pp. 85-108. 
Dineen, D., Rogan, F. and Gallachóir, B.Ó. (2015), "Improved modelling of thermal energy savings potential in the existing residential stock using a newly available data source", Energy, Vol. 90, pp. 759-767.

Fineman, S. and Clarke, K. (1996), "Green stakeholders: industry interpretations and response", Journal of Management Studies, Vol. 33 No. 6, pp. 715-730.

Frankental, P. (2001), "Corporate social responsibility-a PR invention?", Corporate Communications: An International Journal, Vol. 6 No. 1, pp. 18-23.

Geels, F.W. (2002), "Technological transitions as evolutionary reconfiguration processes: a multi-level perspective and a case-study", Research Policy, Vol. 31 No. 8-9, pp. $1257-$ 1274.

Geels, F.W. (2004), "From sectoral systems of innovation to socio-technical systems: insights about dynamics and change from sociology and institutional theory", Research Policy, Vol. 33 No. 6-7, pp. 897-920.

Geels, F.W. and Schot, J. (2007), "Typology of sociotechnical transition pathways", Research Policy, Vol. 36 No. 3, pp. 399-417.

Ghoshal, S. (2005), "Bad management theories are destroying good management practices", Academy of Management Learning \& Education, Vol. 4 No. 1, pp. 75-91.

Halme, M., Lindeman, S. and Linna, P. (2012), "Innovation for inclusive business: Intrapreneurial bricolage in multinational corporations", Journal of Management Studies, Vol. 49 No. 4, pp. 743-784.

Hervieux, C. and Voltan, A. (2018), "Framing social problems in social entrepreneurship", Journal of Business Ethics, Vol. 151 No. 2, pp. 279-293. 
Hess, D.J. (2018), "Energy democracy and social movements: a multi-coalition perspective on the politics of sustainability transitions", Energy Research \& Social Science, Vol. 40, pp. 177-189.

Hiteva, R. and Sovacool, B. (2017), "Harnessing social innovation for energy justice: a business model perspective", Energy Policy, Vol. 107, pp. 631-639.

Hiteva, R.P. (2013), "Fuel poverty and vulnerability in the EU low-carbon transition: the case of renewable electricity", Local Environment, Vol. 18 No. 4, pp. 487-505.

Hockerts, K. and Wüstenhagen, R. (2010), "Greening Goliaths versus emerging Davidstheorizing about the role of incumbents and new entrants in sustainable entrepreneurship", Journal of Business Venturing, Vol. 25 No. 5, pp. 481-492.

Hörisch, J. (2015), "The role of sustainable entrepreneurship in sustainability transitions: a conceptual synthesis against the background of the multi-level perspective", Administrative Sciences, Vol. 5 No. 4, pp. 286-300.

Jenkins, K., Sovacool, B.K. and McCauley, D. (2018), "Humanizing sociotechnical transitions through energy justice: an ethical framework for global transformative change", Energy Policy, Vol. 117, pp. 66-74.

Jenkins, K.E., Stephens, J.C., Reames, T.G. and Hernández, D. (2020), "Towards impactful energy justice research: transforming the power of academic engagement", Energy Research \& Social Science, Vol. 67, pp. 101510.

Keszey, T. (2018), "Boundary spanners' knowledge sharing for innovation success in turbulent times", Journal of Knowledge Management, Vol. 22 No. 5, pp. 1061-1081. 
Kistruck, G.M. and Beamish, P.W. (2010), "The interplay of form, structure, and embeddedness in social intrapreneurship", Entrepreneurship Theory and Practice, Vol. 34 No. 4, pp. $735-761$.

Leifer, R. and Delbecq, A. (1978), "Organizational/environmental interchange: a model of boundary spanning activity", Academy of Management Review, Vol. 3 No. 1, pp. 40-50.

Littlewood, D. and Khan, Z. (2018), "Insights from a systematic review of literature on social enterprise and networks: where, how and what next?", Social Enterprise Journal, Vol. 14 No. 4, pp. 390-409.

Loorbach, D. and Wijsman, K. (2013), "Business transition management: exploring a new role for business in sustainability transitions", Journal of Cleaner Production, Vol. 45, pp. 20 28.

Mair, J. and Marti, I. (2006), "Social entrepreneurship research: a source of explanation, prediction, and delight", Journal of World Business, Vol. 41 No. 1, pp. 36-44.

Margolis, J.D. and Walsh, J.P. (2003), "Misery loves companies: rethinking social initiatives by business", Administrative Science Quarterly, Vol. 48 No. 2, pp. 268-305.

Martiskainen, M., Heiskanen, E. and Speciale, G. (2018), "Community energy initiatives to alleviate fuel poverty: the material politics of Energy Cafés", Local Environment, Vol. 23 No. 1, pp. 20-35.

Mitchell, R.K., Agle, B.R. and Wood, D.J. (1997), "Toward a theory of stakeholder identification and salience: defining the principle of who and what really counts", Academy of Management Review, Vol. 22 No. 4, pp. 853-886. 
Maon, F., Lindgreen, A., \& Swaen, V. (2010). Organizational stages and cultural phases: A critical review and a consolidative model of corporate social responsibility development. International Journal of Management Reviews, 12(1), 20-38.

Montgomery, A.W., Dacin, P.A. and Dacin, M.T. (2012), "Collective social entrepreneurship: collaboratively shaping social good", Journal of Business Ethics, Vol. 111 No. 3, pp. $375-388$.

Nandan, M., London, M. and Bent-Goodley, T. (2015), "Social workers as social change agents: social innovation, social intrapreneurship, and social entrepreneurship", Human Service Organizations: Management, Leadership \& Governance, Vol. 39 No. 1, pp. 38-56.

Nelson, J. and Jenkins, B. (2006), Investing in Social Innovation: Harnessing the Potential of Partnership between Corporations and Social Entrepreneurs. Corporate Social Responsibility Initiative Working Paper No. 20, Harvard University, Cmbridge, MA.

Nicholls, A. (2010). The legitimacy of social entrepreneurship: Reflexive isomorphism in a preparadigmatic field. Entrepreneurship theory and practice, 34(4), 611-633.

Nicholls, A. and Teasdale, S. (2017), "Neoliberalism by stealth? Exploring continuity and change within the UK social enterprise policy paradigm", Policy \& Politics, Vol. 45 No. 3, pp. 323-341.

Okkonen, L. and Lehtonen, O. (2016), "Socio-economic impacts of community wind power projects in Northern Scotland", Renewable Energy, Vol. 85, pp. 826-833.

Pareja-Cano, B., Valor, C. and Benito, A. (2020), "How social enterprises nurture empowerment: a grounded theoretical model of social change", Journal of Social Entrepreneurship, doi: 10.1080/19420676.2020.1821753. 
Parmar, B.L., Freeman, R.E., Harrison, J.S., Wicks, A.C., Purnell, L. and De Colle, S. (2010), "Stakeholder theory: the state of the art", Academy of Management Annals, Vol. 4 No. 1, pp. 403-445.

Perez-Arriaga, I.J., Jenkins, J.D. and Batlle, C. (2017), "A regulatory framework for an evolving electricity sector: highlights of the MIT utility of the future study", Economics of Energy \& Environmental Policy, Vol. 6 No. 1, pp. 71-92.

Rotmans, J. and Loorbach, D. (2009), "Complexity and transition management", Journal of Industrial Ecology, Vol. 13 No. 2, pp. 184-196.

Santamouris, M. (2016), "Innovating to zero the building sector in Europe: minimising the energy consumption, eradication of the energy poverty and mitigating the local climate change", Solar Energy, Vol. 128, pp. 61-94.

Schoenmaker, D. (2017), "From risk to opportunity: a framework for sustainable finance", RSM Series on Positive Change, Vol. 2, doi: 10.2139/ssrn.3125351.

Schot, J. and Geels, F.W. (2008), "Strategic niche management and sustainable innovation journeys: theory, findings, research agenda, and policy", Technology Analysis \& Strategic Management, Vol. 20 No. 5, pp. 537-554.

Smith, A. (2007), "Translating sustainabilities between green niches and socio-technical regimes", Technology analysis \& strategic management, Vol. 19 No. 4, pp. 427-450.

Sovacool, B.K. (2014), "What are we doing here? Analyzing fifteen years of energy scholarship and proposing a social science research agenda", Energy Research \& Social Science, Vol. 1, pp. 1-29.

Sovacool, B.K., Burke, M., Baker, L., Kotikalapudi, C.K. and Wlokas, H. (2017), "New frontiers and conceptual frameworks for energy justice", Energy Policy, Vol. 105, pp. 677-691. 
Sovacool, B.K. and Dworkin, M.H. (2015), "Energy justice: conceptual insights and practical applications", Applied Energy, Vol. 142, pp. 435-444.

Suddaby, R., Bitektine, A. and Haack, P. (2017), "Legitimacy", Academy of Management Annals, Vol. 11 No. 1, pp. 451-478.

Summers, D.B. and Dyck, B. (2011), "A process model of social intrapreneurship within a forprofit company: first Community Bank", Lumpkin, G.T. and Katz, J.A. (Eds.), Social and Sustainable Entrepreneurship, Emerald Group Publishing Limited, Bingley, pp. 139-174.

Sumner, A., Hoy, C. and Ortiz-Juarez, E. (2020), Estimates of the Impact of COVID-19 On Global Poverty, WIDER Working Paper 2020/43, UNU-WIDER, Helsinki.

Thomson, H. and Bouzarovski, S. (2018), Addressing Energy Poverty in the European Union: State of Play and Action, EU Energy Poverty Observatory, University of Manchester, England.

Turnheim, B. and Sovacool, B.K. (2019), "Forever stuck in old ways? Pluralising incumbencies in sustainability transitions", Environmental Innovation and Societal Transitions, Vol. 35, pp. 180-184.

van Tulder, R. (2018), Business \& the Sustainable Development Goals: A Framework for Effective Corporate Involvement, Erasmus University, Rotterdam.

Van Tulder, R. and Keen, N. (2018), "Capturing collaborative challenges: designing complexitysensitive theories of change for cross-sector partnerships", Journal of Business Ethics, Vol. 150 No. 2, pp. 315-332.

Van Zanten, J.A. and Van Tulder, R. (2018), "Multinational enterprises and the sustainable development goals: an institutional approach to corporate engagement", Journal of International Business Policy, Vol. 1 No. 3, pp. 208-233. 
Waddock, S., Meszoely, G.M., Waddell, S. and Dentoni, D. (2015), "The complexity of wicked problems in large scale change", Journal of Organizational Change Management, Vol. 28 No. 6, pp. 993-1012.

Weick, K.E. and Quinn, R.E. (1999), "Organizational change and development", Annual Review of Psychology, Vol. 50 No. 1, pp. 361-386.

Wesseling, J.H., Bidmon, C. and Bohnsack, R. (2020), "Business model design spaces in sociotechnical transitions: the case of electric driving in the Netherlands", Technological Forecasting and Social Change, Vol. 154, p. 119950.

Winn, M.I. (2001), "Building stakeholder theory with a decision modeling methodology", Business \& Society, Vol. 40 No. 2, pp. 133-166. 
